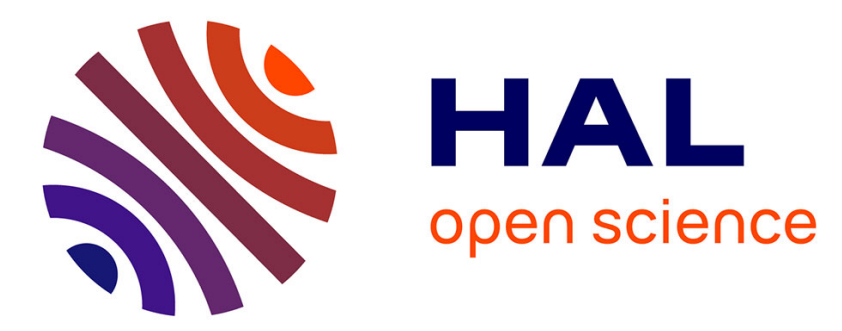

\title{
Climate variability and storm impacts as major drivers for human coastal marsh withdrawal over the Neolithic period (Southern Brittany, NW France)
}

A. Fernane, Aurélie Pénaud, Emmanuel Gandouin, Jean Goslin, Brigitte van Vliet-Lanoë, M. Vidal

\section{To cite this version:}

A. Fernane, Aurélie Pénaud, Emmanuel Gandouin, Jean Goslin, Brigitte van Vliet-Lanoë, et al.. Climate variability and storm impacts as major drivers for human coastal marsh withdrawal over the Neolithic period (Southern Brittany, NW France). Palaeogeography, Palaeoclimatology, Palaeoecology, 2015, 435, pp.136-144. 10.1016/j.palaeo.2015.05.029 . hal-01445162

\author{
HAL Id: hal-01445162 \\ https://hal.science/hal-01445162
}

Submitted on 6 Oct 2020

HAL is a multi-disciplinary open access archive for the deposit and dissemination of scientific research documents, whether they are published or not. The documents may come from teaching and research institutions in France or abroad, or from public or private research centers.
L'archive ouverte pluridisciplinaire HAL, est destinée au dépôt et à la diffusion de documents scientifiques de niveau recherche, publiés ou non, émanant des établissements d'enseignement et de recherche français ou étrangers, des laboratoires publics ou privés. 


\title{
Fernane et al. 2015. Climate variability and storm impacts as major drivers for human coastal marsh withdrawal over the Neolithic period (Southern Brittany, NW France). Palaeogeography, Palaeoclimatology, Palaeoecology 435: 136-144
}

\section{Climate variability and storm impacts as major drivers for human coastal marsh withdrawal over the Neolithic period (Southern Brittany, NW France)}

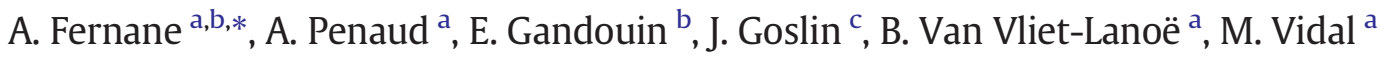 \\ a UMR 6538 Domaines Océaniques, IUEM-UBO, Brest University, UEB, rue Dumont d'Urville, 29280 Plouzané, France \\ b IMBE, UMR 7263 CNRS-IRD-UAPV, Aix-Marseille University, Europôle Méditerranéen de l'Arbois, Pavillon Villemin, BP 80, 13545 Aix-en-Provence Cedex 04, France \\ c UMR 6554 CNRS LETG-Geomer, IUEM-UBO, Brest University, UEB, rue Dumont d'Urville, 29280 Plouzané, France
}

\section{A R T I C L E I N F O}

\section{Article history:}

Received 3 December 2014

Received in revised form 17 April 2015

Accepted 27 May 2015

Available online 6 June 2015

\section{Keywords:}

Holocene

Brittany coastal area

Foraminifera

Pollen

Human settlement

Climate variability

\begin{abstract}
A B S T R A C T
Relationships between climate variations, vegetation dynamics, and early human activities during the Neolithic have been reconstructed from high-resolution pollen and foraminiferal records obtained from cores retrieved from coastal wetland located in southern Brittany (Guidel, NW France). Our data show that the area around Guidel corresponded to a dense temperate forest locally replaced by riparian forest in the marsh, without any human disturbance during the early Neolithic. During the mid-Neolithic, between 6500 and 5500 cal years BP, the first episode of probable human settlement is recorded, as suggested by the increase of anthropogenic plants. This early record of human impact is consistent with archeological studies that find a high concentration of funeral monuments around Guidel during this cultural period. This complex first phase is interrupted by the disappearance of anthropogenic influence coinciding with a cold/humid climate period in the region characterized by recurrent major storms. Then, at the transition between the middle to late Neolithic, at 5500 cal years BP, a second phase of human retreat is signaled by both vegetation dynamics and archeological records; this interval also coincides with a climatic deterioration marked by cold/humid conditions recorded in the region (Sorrel et al., 2012). The results of the present study imply that human settlement/departure over the Neolithic was probably influenced by climatic variations. During the Bronze Age, Iron Age, and Middle Ages, a progressive decline of the arboreal forest, synchronous with an increase of anthropogenic plants, confirms the high and persistent human activity around the site. Furthermore, our results at Guidel suggest a different anthropogenic trend recorded between north and south Brittany. The human impact is well recorded during the Neolithic at Guidel, while in northern Brittany human settlement is not recorded before the Bronze Age, consistent with existing archeological data.
\end{abstract}

\section{Introduction}

High-resolution paleoclimate and paleoenvironmental studies over the Holocene are crucial in order to understand past forcing mechanisms and future climate trends superimposed on increasing human impacts. Millennial-scale climate oscillations are now well recognized throughout the Holocene (O'Brien et al., 1995; Bond et al., 2001; Mayewski et al., 2004; Wanner et al., 2011) and there is a rise in paleoclimate studies worldwide so as to better understand the nature, timing, and causes of these oscillations, e.g. solar activity and/or internal forcing mechanisms relative to the climate system, and the changing atmospheric and oceanic re-organizations through time (Bond et al.,

\footnotetext{
* Corresponding author at: UMR 6538 Domaines Océaniques, IUEM-UBO, Brest University, UEB, rue Dumont d'Urville, 29280 Plouzané, France. Tel.: + 33634068661.

E-mail addresses: assia.fernane@gmail.com (A. Fernane), aurelie.penaud@univ-brest.fr (A. Penaud).
}

2001; Mayewski et al., 2004; Wanner et al., 2008, 2011; Fletcher et al. 2013). Holocene mechanisms and global-scale representations of climate are still far from being well-understood and regional studies are required to understand the spatiotemporal complexity of our interglacial period.

This is especially true at a local scale when considering coastal zones that evolve fast, specifically to global changes including sea level, air temperature, continental precipitation changes, and human disturbances. Bio-indicator analyses are therefore crucial for detecting ecosystem changes in response to climatic and anthropogenic controls. Maritime marshes are remarkable coastal ecosystems in temperate regions, with dynamic ecological systems responding to changing environmental conditions such as sea level or river discharge variations. Hence, they are influenced by both continental and marine factors. The Grand Loc'h (GL) of Guidel, located south of Brittany (NW France, Fig. 1), consists of an ancient ria progressively transformed into a coastal salt marsh during the Holocene transgression. It is protected from direct 
a)

b)

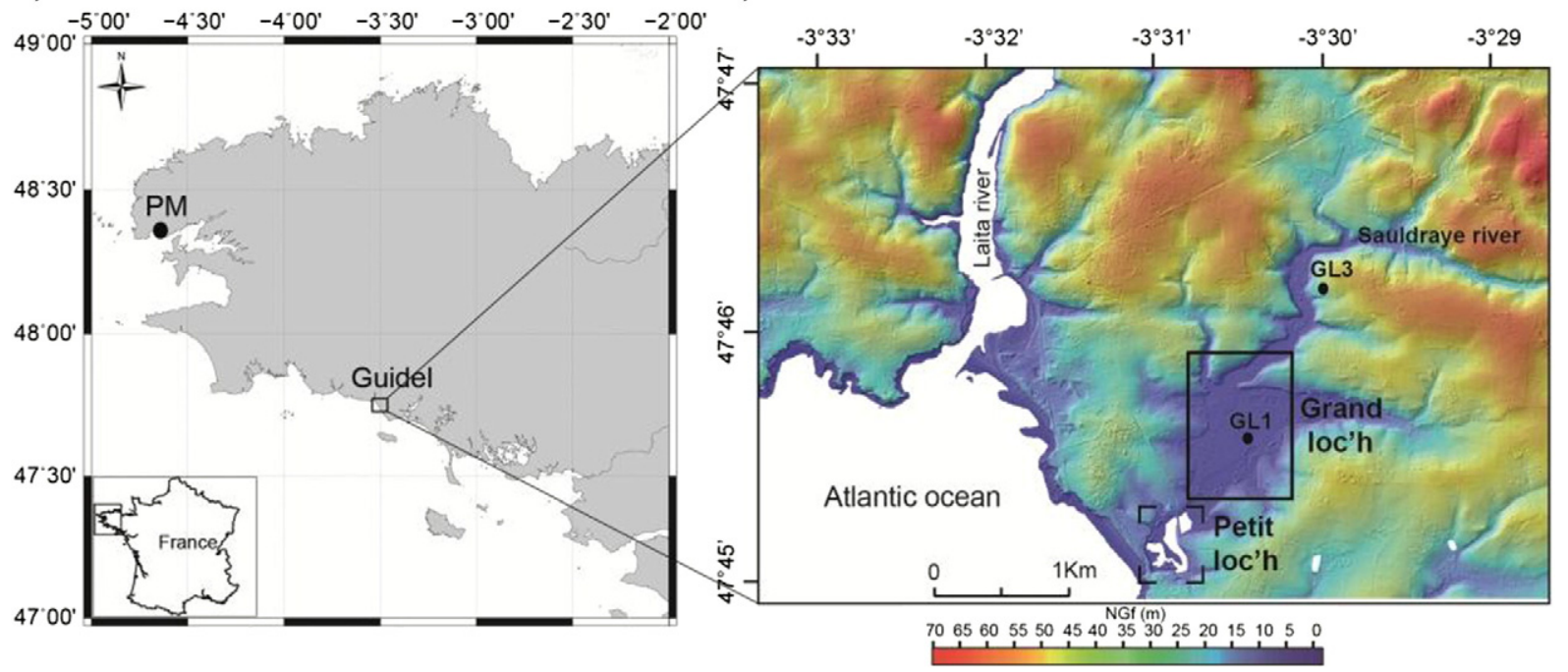

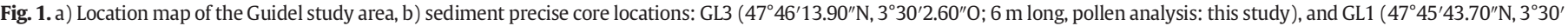
$10.75^{\prime \prime} \mathrm{O} ; 11 \mathrm{~m}$ long, foraminiferal analysis: Fernane, 2014).

marine intrusion by a late Holocene sandy dune barrier. The GL marsh is therefore a perfect area to perform paleoenvironmental studies of the Holocene period using comprehensive sediment records. Additionally, several studies conducted around Brittany previously confirmed that coastal environments represent pertinent and key study areas to decipher Holocene climatic and/or anthropogenic changes (Sorrel et al., 2009, 2012; Baltzer et al., 2014; Fernane et al., 2014; Van Vliet-Lanoë et al., 2014).

Based on pollen analysis conducted on a sediment core retrieved from southern Brittany, we discuss the paleoenvironmental history of the region over the last 7000 cal years BP. Pollen analyses will allow us to discuss, in parallel, both climate fluctuations and agro-pastoral activities over the surrounding GL watersheds. Hence, the present paleoenvironmental study should enable us to: 1 ) detect past environment changes, 2) try to relate these changes to the climate pattern, and 3) supply information about the impact of human expansion on ecosystems through time.

\section{Environmental context}

\subsection{Geomorphological context}

The study area, Guidel ("Grand Loc'h”, GL, Fig. 1), is a maritime coastal marsh located in southern Brittany (NW France). The site is fully incised in weathered Paleozoic bedrock; the gneiss is saprolite, mostly impervious, and induces rapid and superficial drainage over the watershed as well as toward the ocean. Despite its present low altitude, less than +2 m NGF ("Nivellement Général de la France", French reference system for sea level elevation), and the prevailing macro-tidal regime, the marsh is protected from marine intrusion by a coastal dune ridge. Since 1989, these coastal dunes support a road that isolates GL from a sandy beach about $500 \mathrm{~m}$ long (Fig. 1).

The present-day GL marsh surface, stretching from north to south, covers 70 ha, and its surrounding catchment covers about 2600 ha. GL marsh consists of two asymmetrical parts: the northern part or "Grand Loc'h" (GL) and the southern part or "Petit Loc'h" (PL), this latter being partly embanked during the 1960s (Fig. 1). The two parts are separated by a small dam constructed during the 19th century in order to stop marine intrusion toward GL and to allow agriculture activities. Furthermore, between 1942 and 1945, the Germans created an airport, the superficial ground scraping then perturbed the top of the stratigraphical sequence. According to these anthropogenic morphological configurations, hydrological differences can be observed between the GL and PL Loc'hs. Brackish hydrological conditions dominate in PL due to its connection to the sea via a tide gate (1884 AD). During the summer period, PL is dry with few permanent brackish ponds, while the rest of the year PL marsh is subject to marine submersion. In contrast, the GL surface waters today are fully protected from the influence of seawater, and GL shows more complex environmental processes over the year. Hence, the GL marsh is subject to fluctuating fresh (river discharges) and marine water conditions (via PL) from winter to late spring while, during late summer, the marine water prism may reach the surface, resulting in brackish to salty vegetation establishment. In the upstream part of GL, a persistence of high groundwater levels leads to a continuous freshwater peat development, within a depression separated from the Sauldraye river by a fluvial sandy bank (Fig. 1a). The spatial heterogeneity of the Guidel marsh, consisting in a total of $5 \mathrm{~km}$ of channeled rivers, as well as in permanent/temporary small ponds, offers diversified and numerous habitats for floral and faunal species.

\subsection{Present-day climate and associated vegetation}

The climate in Brittany is characterized by temperate oceanic conditions (due to the North Atlantic Ocean influence) with generally cool, rainy winters and fresh summers. Mean annual temperature ranges between 10.9 and $12.6{ }^{\circ} \mathrm{C}$ with weak thermic seasonal amplitudes. Mean annual precipitation rate ranges from 800 to $850 \mathrm{~mm}$. The climate of Brittany is strongly influenced by the North Atlantic Oscillation (NAO) pattern that governs the strength and persistence of the westerly winds (Hurrell, 1995). This natural pattern of atmospheric variability directly influences temperatures and hydrological conditions (precipitation, river discharges, and water table levels), which in turn influence vegetation cover.

Regarding current vegetation, the Guidel marsh was extensively cultivated until the last decade of the 20th century. Nowadays, only pastoral activities continue. In this area, vegetation is constituted by several kinds of meadows characterized by associations of different species. Among these, notable and rare species are observed, such as Salicornia ramosissima, Puccinellia distans, Agrostis stolonifera, Potamogeton crispus, Eleocharis palustris, Trifolium fragiferum, Trifolium resupinatum, Prunus sp., and Potentilla neumanianna. Some other species such as Carex punctata, and Orchis laxiflora are classified as endangered species. The landscape throughout the Guidel marsh is mainly open and the sparse 
and scattered woodland of the surrounding area is dominated by Salix, Quercus, Fraxinus, Fagus, and Corylus.

\section{Archeological context}

Human settlement and development in Brittany are shown by several well-preserved coastal archeological sites and megalith monuments erected between 6700 and 4000 cal years BP. At Guidel, the presence of several megaliths attest to high human settlement during the Neolithic in this area. Numerous studies carried out in this region were mainly focused on architectural and typological issues, however information related to human organization, occupation strategy, and spatial distribution are still under-documented (López-Romero González de la Aleja, 2008). Furthermore, data related to the beginning of agricultural activities are discrete and still debated. Several studies based on pollen reconstructions from the Armorican Domain have reported the presence of Cerealia pollen grains in association with ruderal taxa such as Plantago lanceolata since the late Mesolithic (8700 cal BP) (Visset et al., 1996; Joly and Visset, 2009). These works suggested an early regional Neolithization. Nevertheless, this hypothesis has been rejected by Marchand $(2005,2014)$ because of issues regarding pollen identification and chrono-stratigraphical uncertainties. Then, from the Bronze Age (4500-1450 cal BP) to the Middle Ages (1450-450 cal BP), southern Brittany was subjected to persistent and increasing agro-pastoral activities. Nowadays and since the 1970s ("green agricultural revolution"), Brittany has become a leading French agricultural region.

In Brittany, evidence for Neolithic wooden houses is rare and it is difficult, if not impossible, to infer the size, structure, and distribution of the Neolithic population, i.e. paleodemographics, at that time. However, funeral stone monuments are abundant all over Brittany and the concentration of these Neolithic structures in the region is the highest recorded in France (Blanchard, 2012). The Neolithic is commonly divided into three sub-periods, early, middle, and late Neolithic (early Neolithic: 8500-6700 cal BP, mid-Neolithic: 6700-5500 cal BP; late Neolithic: $5500-4500$ cal BP), each period being marked by specific burial monuments (Giot et al., 1981). The concentration of these monuments is then indirectly used to infer human densities. Migratory population dynamics may then be reconstructed by careful study of the spatial distribution of the burial monuments through time. At Guidel and its surroundings, numerous archeological explorations have been carried out and recent inventories exist for the Neolithic cultural period (Gouézin, 1994, 2007; González de la Aleja, 2008; Nicolas et al., 2013; Pailler and Nicolas, 2014).

\section{Methods}

\subsection{Field work and radiocarbon analyses}

The Guidel core (GL3: $47^{\circ} 46^{\prime} 13.90^{\prime \prime} \mathrm{N}, 3^{\circ} 30^{\prime} 2.60^{\prime \prime} \mathrm{O} ; 6 \mathrm{~m}$ long) was extracted with a Russian corer from a freshwater peatbog, core sections are $1 \mathrm{~m}$ long and $8 \mathrm{~cm}$ wide. Eleven sediment samples composed of bulk peat were dated using the conventional radiocarbon method AMS ${ }^{14} \mathrm{C}$ (Table 1). Sampling was performed prior to the palynological study, before any oxydation of the organic matter, both above and below macroscopic changes in peat fabric. Calibration of all dates was performed at $2 \sigma$ using the Clam program (version 2.2; Blaauw, 2010) associated with the statistical software R (version 3.0.1; "R Development Core Team”, 2013). Non-marine (IntCal13) AMS ${ }^{14} \mathrm{C}$ dates were converted to calendar ages using the radiocarbon calibration curve (Reimer et al., 2013). The age model of the GL3 core is based on linear interpolation between the ten radiocarbon dates obtained from the core (Fig. 3).

\subsection{Pollen analysis}

Seventy-seven samples were analyzed for pollen on the GL3 peat core with a sampling resolution ranging from 5 (Neolithic period) to $10 \mathrm{~cm}$. The pollen extraction followed the classical technique (Moore et al., 1991) in which samples are treated by $10 \% \mathrm{NaOH}$ (10 min), $10 \%$ $\mathrm{HCl}(24 \mathrm{H}), 58 \% \mathrm{HF}(24 \mathrm{H})$, and then warm concentrated $\mathrm{HCl}(15 \mathrm{~min})$ followed by acetolysis ( $5 \mathrm{~min}$ ). Pollen frequencies are expressed relative to the main pollen sum composed of trees and herbs; Pinus, helophytic and hydrophytic plants, Pteridophyta (monolete and trilete spores), and Cyperaceae were excluded from this main pollen sum. Riparian forest pollens, including Alnus, Salix, Fraxinus, and Chenopodiaceae pollen grains were also excluded from the total pollen sum since they are over represented in coastal marsh environments. A minimum of 300 pollen grains per sample (out of excluded taxa) were counted under a transmitted light microscope at $\times 1000$ magnification. In this study, pollen types have been identified according to Hyde and Adams (1958), Moore et al. (1991), Nilsson et al. (1977), and Reille (1995, 1999).

\section{Pollen assemblages (GL3 core)}

The radiocarbon dates suggest that the well-preserved GL3 core covers the last 7000 years (Fig. 2). This sediment record is characterized by homogeneous and continuous sediments, mainly composed of peat deposits (Fig. 2).

Table 1

List of all ${ }^{14} \mathrm{C}$ dating obtained on Guidel cores ( ${ }^{*}$ rejected dates for GL stratigraphy).

\begin{tabular}{|c|c|c|c|c|c|c|}
\hline Depth (m) & $\begin{array}{l}\text { Altitude NGF } \\
(\mathrm{m})\end{array}$ & Laboratory code & Dated material & ${ }^{14} \mathrm{C}$ date $\mathrm{BP}$ & Age cal. BP min-max & Age cal. BP mean \\
\hline \multicolumn{7}{|c|}{$G L 1+1.73 \mathrm{~m} \mathrm{NGF}$} \\
\hline 1.6 & 0.33 & Poz-49809 & Bulk & $1760 \pm 35$ & $1567-1740$ & 1653 \\
\hline 1.7 & 0.23 & Poz-49805 & Bulk & $1300 \pm 70$ & $1062-1332$ & 1197 \\
\hline 3.7 & -1.97 & Poz-49806 & Scrobicularia & $4395 \pm 35$ & $4480-4783$ & 4631 \\
\hline 9.6 & -7.87 & Poz-47039 & Bulk & $6650 \pm 40$ & $7459-7587$ & 7523 \\
\hline \multicolumn{7}{|c|}{$G L 3+2, .20 \mathrm{~m} \mathrm{NGF}$} \\
\hline 0.53 & 1.67 & SacA 29575 & Bulk & $760 \pm 30$ & $667-729$ & 698 \\
\hline 0.85 & 1.35 & SacA 29576 & Bulk & $1585 \pm 30$ & $1407-1542$ & 1474 \\
\hline 1.88 & 0.32 & SacA 29578 & Bulk & $2905 \pm 30$ & $2957-3083$ & 3020 \\
\hline 2.23 & -0.03 & SacA 29577 & Bulk & $3050 \pm 30$ & $3174-3350$ & 3262 \\
\hline 2.64 & -0.44 & SacA 29579 & Bulk & $3730 \pm 30$ & $3981-4154$ & 4067 \\
\hline 3.02 & -0.82 & SacA 29580 & Bulk & $4105 \pm 30$ & $4521-4663$ & 4592 \\
\hline 3.74 & -1.54 & SacA 29581 & Bulk & $4605 \pm 30$ & $5377-5450$ & 5413 \\
\hline 4.34 & -2.14 & SacA 29582 & Bulk & $4930 \pm 30$ & $5600-5719$ & 5659 \\
\hline 4.92 & -2.72 & SacA 29583 & Bulk & $* 5380 \pm 30$ & & \\
\hline 5.33 & -3.13 & Poz-49810 & Bulk & $5450 \pm 40$ & 6186-6308 & 6247 \\
\hline 5.92 & -3.72 & SacA 29584 & Bulk & $6105 \pm 30$ & $6889-7030$ & 6960 \\
\hline
\end{tabular}




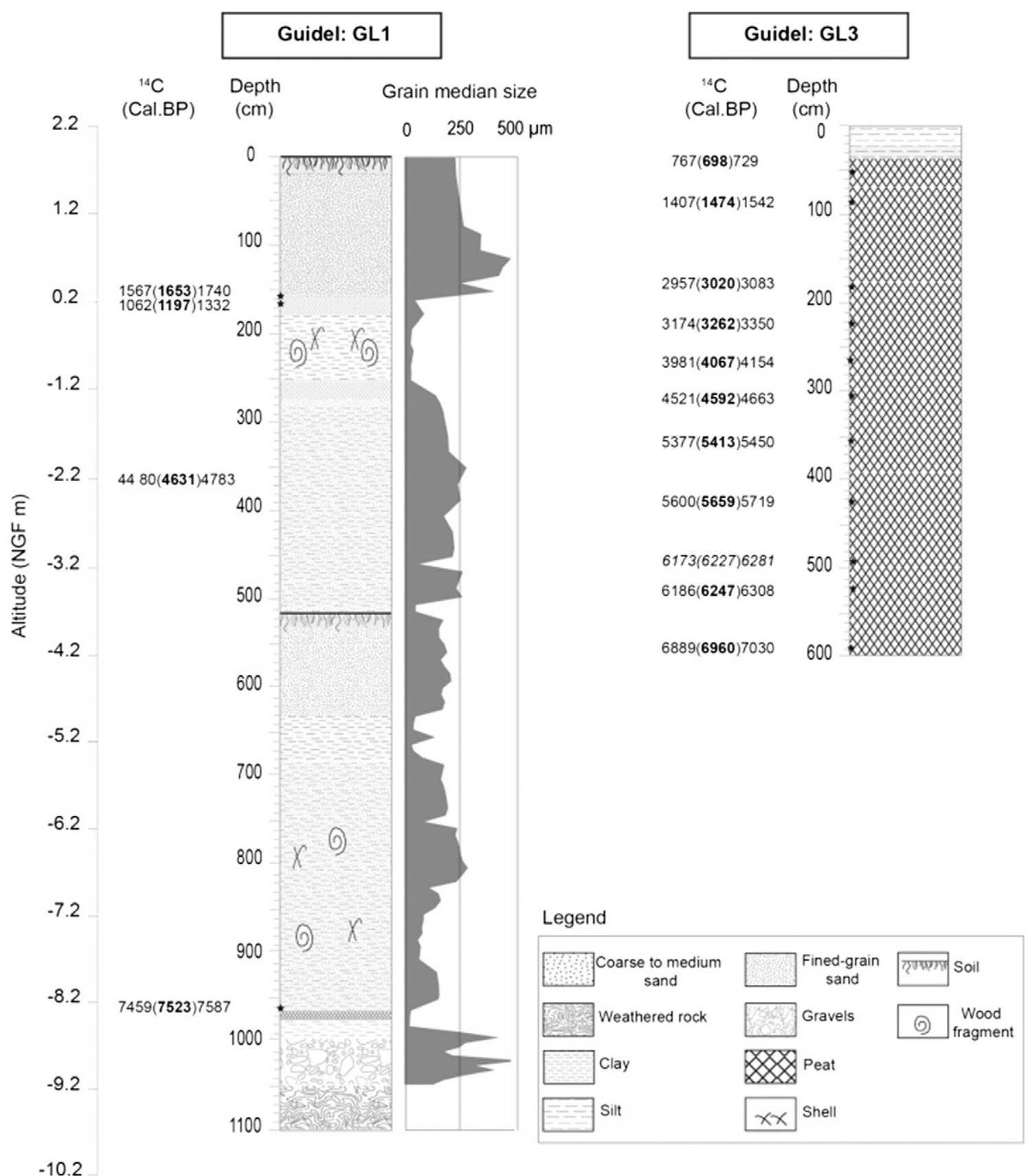

Fig. 2. Stratigraphic logs of the 2 study cores GL1 and GL3: lithofacies (modified from Goslin, 2014) and granulometric analyses.

Ninety-four different pollen taxa have been identified on the GL3 core. Distribution of main pollen taxa (recorded at least once $>2 \%$ ) observed in the core is shown in Fig. 5, as well as Castanea and Juglans distributions (even if recorded below $2 \%$ ). Based on the evolution of arboreal pollen (AP) percentages, three main palynozones have been established (GL3p1 to GL3p3) using Broken stick model (Bennett, 1996), and additional zones were added visually. Subsequently, additional sub-zones have been proposed based on some specific taxa dynamics (Fig. 4). Overall, our pollen analysis shows a progressive transformation of both the marsh and its surrounding catchment, from a closed/wooded area to an open/cultivated or meadow area.

The first palynozone (GL3p1: 6989-5689 cal BP) is characterized by high AP percentages ( $80 \%$ in average). Pollen results characterize GL3p1 as a sub-zone (5618-4618 cal BP) (90\% of deciduous Quercus and Corylus), suggesting the establishment of a temperate continental mixed oak forest around the site, on the drained watershed. Synchronously, in the marsh, Alnus is the dominant wetland tree with percentages reaching $40 \%$ on average. High percentages of Plantago (up to $20 \%$ ) together with low percentages of Artemisia and some occurrences of Cerealia, are also recorded in this sub-zone which suggests probable episodes of landscape clearance. Nevertheless, very low values of Cerealia cannot allow us to categorically attribute this clearance event to human activities such as agricultural practices. Plantago extension is currently attributed to extensive trampling and nitrogenous enrichment of soils by megafauna (Stewart, 1996). Hence, significant representation of Plantago, associated to the attested record of an open landscape through occurrences of Artemisia and Poaceae, could be related to probable pastoral activities in the Guidel marsh. At the start of GL3p1b (4618-3602 cal BP), the sharp decrease of Plantago, Artemisia, and Poaceae, accompanied by a rise in AP percentages such as Tilia, suggest the recovery of the forest. Quercus shows increasing percentages within the following sub-zone GL3p1c (3602-3249 cal BP) where its 


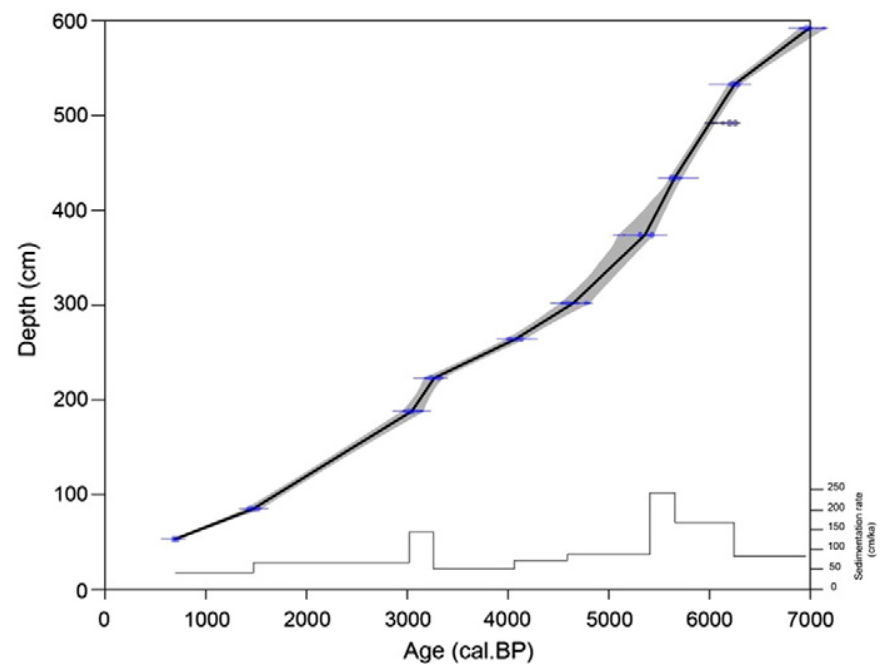

Fig. 3. Calendar age-depth model based on ten ${ }^{14} \mathrm{C}$ dates obtained from GL3 (cf. Table 1).

highest values are recorded (up to 65\%), while Corylus and Ulmus decrease significantly.

The second palynozone (GL3p2: 3249-2697 cal BP) is marked by a sharp then progressive decrease of arboreal taxa (60\% in average), synchronous with the first rise of several anthropogenic taxa abundances such as Humulus/Cannabis and Rumex. This rise is accompanied by: (i) increasing percentages of steppic plants such as Artemisia, and (ii) the first continuous presence of the Cerealia pollen type. More specifically, within GL3p2a (2697-2006 cal BP), a sharp decrease of arboreal taxa associated with an increase in herbs such as Caryophyllaceae and Artemisia is observed, later followed by an increase in Cannabis/ Humulus and Artemisia within GL3p2b (2006-1548 cal BP). This marks the beginning of the arboreal forest collapse in the area. This trend is strongly expressed in GL3p2c, where low percentages of trees such as Quercus and Corylus are observed. Tilia definitively disappears, Alnus percentages strongly decrease, and high percentages of Poaceae are also recorded.

Finally, pollen results within the GL3p3 (1548-694 cal BP) zone show a continuous decrease of AP percentages in parallel with the rapid and progressive rise of agricultural pollen markers, i.e. Cerealia type pollen grains ( $20 \%$ on average). Sub-zone GL3p3a is marked by a second drastic collapse of Corylus and Quercus, while Poaceae increase sharply. Within the GL3p3b sub-zone, Juglans and Castanea occur for the first time, probably growing into the surrounding cleared woodland. Anthropogenic taxa such as Fagopyrum occur at the end of the sub-zone. Synchronously, the wetland tree Salix, as well as aquatic/marsh taxa such as Sparganium, increase. Within the last sub-zone, GL3p3c, agricultural activity appears to be at a maximum, as suggested by the highest Cerealia percentages (about 20\%) of the pollen record. Fagopyrum, Plantago, and Cannabis/Hummulus occurrences then suggest diversified human activities at the end of the record.

\section{Discussion}

6.1. Mid-Holocene vegetation changes recorded at Guidel (6500-5000 cal $B P)$

At a regional scale (Brittany), vegetation dynamics at Guidel show coherent palynological trends corresponding to Holocene climatic and anthropogenic forcing (Morzadec-Kerfourn, 1974; Fernane et al. 2014), however at a local scale substantial differences are observed. Indeed, important differences exist between sub-regional areas making it difficult to model vegetation dynamics for the entire Brittany region (Gaudin, 2004). This highlights the necessity to undertake several local palynological studies in order to establish a precise paleoenvironmental scenario, as proposed in a recent synthesis of Holocene palynological studies in the Parisian Basin (David, 2014). At Guidel, significant occurrences of herbaceous taxa such as Poaceae, Plantago, and other ruderal plants, coupled with rare occurrences of Cerealia pollen grains, and decreasing percentages of arboreal taxa (Quercus) as well as riparian forest (Alnus), may suggest a moderate human presence in the area during the mid-Neolithic, from 6500 to 5500 cal BP (Fig. 5). Previous studies based on archeological evidence, suggest the start of anthropogenic forest clearance at $7000 \mathrm{cal} \mathrm{BP}$ (Marchand, 2014). Paleobotanical evidence in the Gulf of Morbihan, situated $35 \mathrm{~km}$ east of the Guidel marsh, also notes the occurrence of clearance events since the early Neolithic period (Visset, 1994; Visset et al., 1996). Finally, other studies based on pedological evidence have reported clear land degradation directly related to agricultural activities during the mid-Neolithic, especially in Brittany's coastal areas (Gebhardt, 1993; Gebhardt and Marguerie, 2006).

In our study, it is interesting to note that during this interval, from 6000 to $5800 \mathrm{cal} \mathrm{BP}$, the anthropogenic pressure at Guidel probably declined, as suggested by the drop of herbaceous and ruderal plant percentages, synchronously with a full absence of Cerealia pollen grains (Fig. 5). The comparison between Guidel and Pors Milin (NW Brittany),

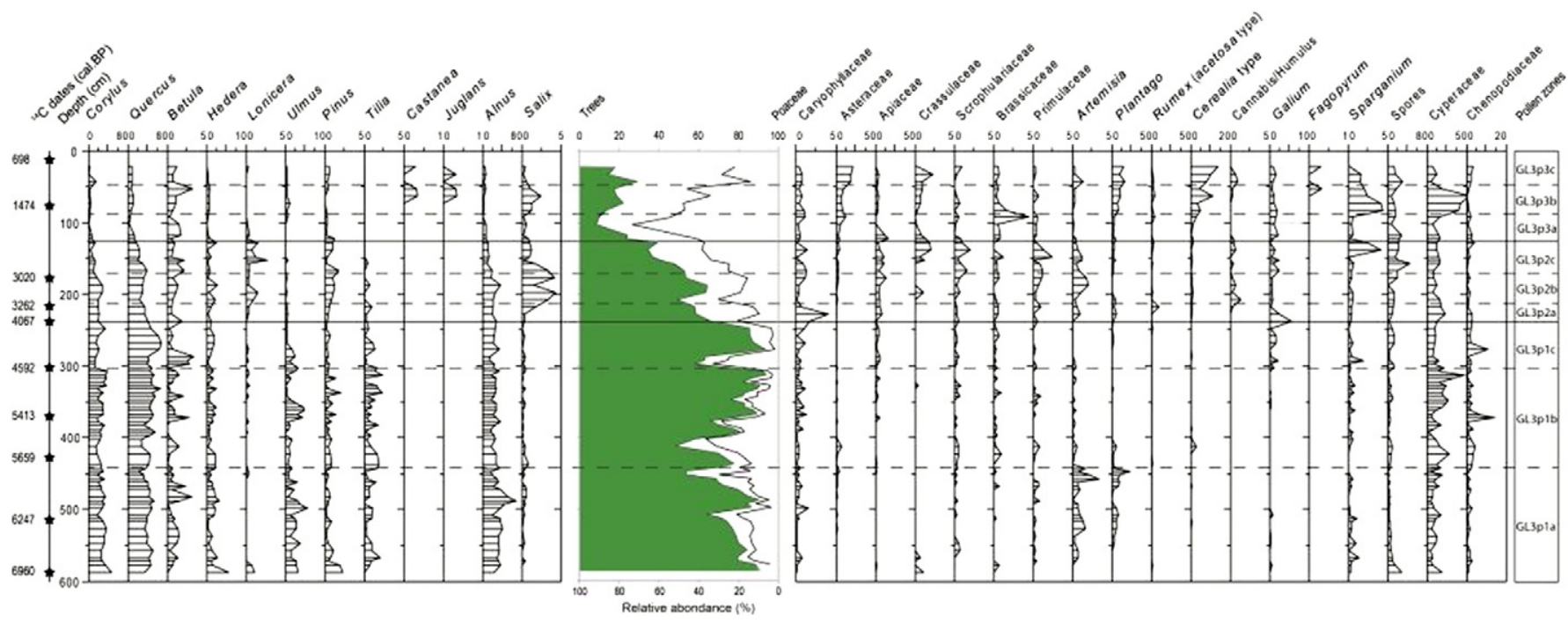

Fig. 4. Percentages of main pollen taxa identified in GL3 core (relative abundances above $>2 \%$ except for Castanea and Juglans). 

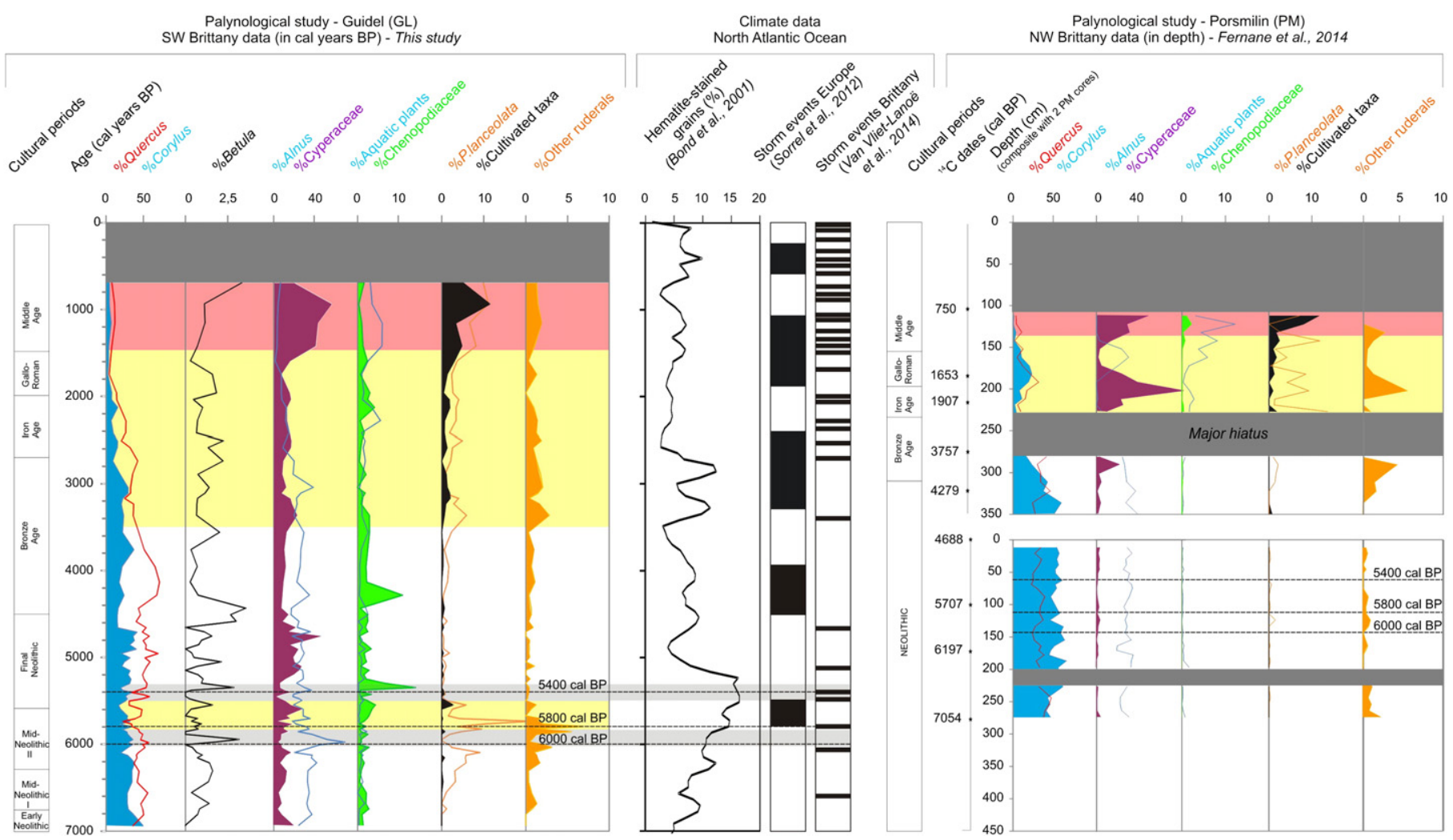

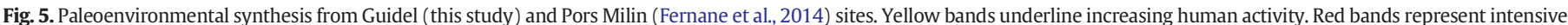

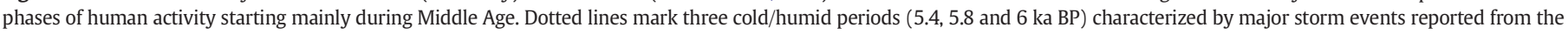

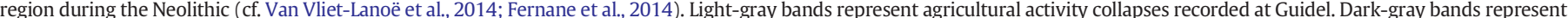

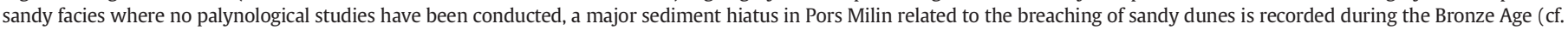
Fernane et al., 2014).

where no human influence is detected until the Bronze Age (Fernane et al., 2014), highlights major differences in regional vegetation trends (Fig. 5). The anthropogenic pressure difference observed between these two areas could be related to different geomorphological contexts. Northern Brittany is characterized by: i) loamy soils, difficult to cultivate with a swing plow, and ii) short and narrow watersheds evolving into narrow coastal marshes, limiting the development of a significant population. In contrast, the southern coast of Brittany is characterized by: i) sandy, easily-cultivated soils, and ii) wide watersheds and large coastal marshes, which probably favored human settlement, especially during the mid-Neolithic period when the sea level was lower $(-7 \mathrm{~m}$; Goslin et al., 2013; Goslin, 2014).

\subsection{Forcing factors responsible for human settlement and departure at Guidel over the mid-Holocene (6500-5500 cal BP)}

Various hypotheses can be assessed to explain the abandonment of GL by the population previously installed on the marsh and its surroundings around $6000 \mathrm{cal} \mathrm{BP}$ (Fig. 5). They can include climatic factors, resistance to adaptation, economic marginalization, mercantile exploration, and hostile neighborhood interaction (D'Andrea et al., 2011). Pollen-based quantitative climate reconstructions (combined with multi-centennial scale paleohydrological data) have been reported from a marine core retrieved in the Bay of Biscay (Naughton et al., 2007), but this kind of data is rare and discontinuous on the Brittany continental sites. It is then difficult to relate our observations to either population displacement, with a socio-economical perspective, or climate change. However, previous studies carried out in Europe have successfully related climate variability and archeological settlement (Magny and Haas, 2004). Indeed, based on hydrological reconstructions from mid-European lakes, Magny and Haas (2004) have previously suggested that human establishment was favored by warm and dry conditions. At Guidel, the sharp decrease of ruderal plants synchronous with maximal values of Alnus growing in waterlogged soils (Barthelmes et al., 2010) suggests the establishment of wetter conditions around the site between 6000 and 5800 cal BP. In coastal areas, Alnus development is controlled by fluctuations of the water table, the latter being influenced by variations in sea level or precipitation. At Guidel, the stability of halophilous plants (e.g. Chenopodiaceae) suggests that wetter conditions probably resulted from increasing precipitation, and not from the expansion of the salt meadows related to the Holocene sea level rise. We thus propose a direct relationship between past hydro-climatic changes and human settlement in the Guidel fluvial and maritime plains.

Climate conditions recorded over Europe suggest sharp climate deterioration between 6500 and 6000 cal BP (Bond et al., 2001; Mayewski et al., 2004) (cf. Fig. 5). Besides, cold and humid conditions were reported between 6300 and $6000 \mathrm{cal}$ BP in French and Swiss alpine lakes (Magny, 2004). Cooler summer temperatures were also reported around 6200-6000 cal BP in Sweden (Grudd et al., 2002), and climate deterioration occurred around 6000 cal BP in Ireland, responsible for a decline of human settlements (Stolze et al., 2013). Recent studies also cited more frequent storms in northwestern Brittany, leading to colder and wetter conditions around 6050 cal BP (Van Vliet-Lanoë et al., 2014; Fig. 5), and the same has also been reported for the western Mediterranean region (Sabatier et al., 2012). We therefore suggest that the collapse of agro-pastoral activities recorded at Guidel around 6050 cal BP could be connected to a climate deterioration characterized by cooler and wetter conditions. Storm-based morphological impacts at the coast are important in Brittany (Van Vliet-Lanoë et al., 2014), and they are mainly indicated by the breaching of coastal barriers and the consecutive recurrent inundation of the formerly-cultivated coastal marsh, which can ultimately result in human retreat. 
After this collapse, and from 5500 to 4500 cal BP, the complete retreat of human presence is confirmed by the absence of cultivated taxa and the subsequent recovery of the forest (Quercus and Corylus) while the riparian forest stays stable (Fig. 5). This period is also marked by a sharp increase of Chenopodiaceae, especially around 5300 cal BP, suggesting marine influences of the study site (Gandouin et al., 2009). Hydrological disturbances in the coastal area, and the consequent human retreat, can either be attributed to more frequent storms or to sea level rise. A regional sea level curve has recently been reconstructed for Brittany, for the last 8000 cal BP, showing sea level rise characterized by progressive decelerating rates with no significant pulses and several stabilization periods around 7000, 6000, 4600, and 3200 cal BP (Goslin et al., 2013; Goslin, 2014). Furthermore, Van Vliet-Lanoë et al. (2014) showed that climatic deterioration marked by major storm events was recorded in western Brittany around 5500 cal BP (Fig. 5). According to pollen data analysis conducted in central Europe (Davis et al., 2003) and Alpine lakes (Magny, 2004), this period of climate deterioration is also recorded on a Europe-wide scale. We therefore suggest that human abandonment during the late Neolithic at Guidel may have been induced by the persistence of cold and frequently humid conditions commonly associated with the recurrence of major storm events (Meurisse-Fort, 2009; Sorrel et al., 2012; Van Vliet-Lanoë et al., 2014). Furthermore, stratigraphic and foraminiferal analyses were also undertaken at Guidel (cf. Figs. 1 and 2 for the location of GL1 core; Fernane, 2014). Main foraminiferal results clearly show successive faunal changes according to two different patterns. The first recorded assemblage is characterized by high percentages of non-calcareous taxa (Trochammina inflata and Jadammina macrescens), while the second type of foraminiferal assemblage is characterized by the dominance of calcareous taxa (Astergerinata mamilla, Haynesina germanica, Elphidium williamsoni, and Lobatula lobatula). From an ecological point of view, it has already been shown that non-calcareous species dominate in the upper part of the salt marsh in Brittany (Rossi et al., 2011; Stéphan et al., 2015) while calcareous foraminifera dominate in sub-tidal, tidal, and marine environments (Liu and Fearn, 1993; Collins et al., 1999; Scott et al., 2001; Murray, 2006). Even if the stratigraphy of GL1 is not robust enough, this sediment sequence is evidence that the downstream part of the Guidel marsh was submitted to continuous marine influences over the last $7000 \mathrm{cal}$ BP (Fernane, 2014) with a high tide level close to -7 m NGF (Goslin et al., 2013; Goslin, 2014). These observations appear consistent with archeological data showing high concentrations of mid-Neolithic passage graves only in the upstream part of the Guidel marsh (Bailloud et al., 1995; Gouézin, 2007). According to Gouézin (2007), no funeral structures are recorded for the downstream part of Guidel. This discrepancy could be explained by recurrent marine inundations at Guidel, especially storm surges and floods, preventing human settlement close to the coast in the study area.

The study of gallery graves (passage graves) shows that human populations previously installed around Guidel moved from the coast inland at that time, as proven by the absence of burial monuments in the surrounding area (Gouézin, 1994, 2007; Pailler and Nicolas, 2014). This is even true during the late Neolithic for the entirety of Morbihan, where archeological data also revealed landward migration at that time (Tanguy and Lagree, 2002; Gaudin, 2004; González de la Aleja, 2008).

\subsection{Land use from Bronze Age to Middle Ages}

At the beginning of the Bronze Age (from 4500 cal BP), Quercus forests are well developed at Guidel suggesting limited human impact on the forest cover (Fig. 5). Archeological studies of population distribution around Guidel show that humans progressively moved inland during the transition between the Neolithic and the Bronze Age (González de la Aleja, 2008; Nicolas et al., 2013). This may explain low percentages of ruderal plants recorded over this period. The reappearance of Plantago, associated with significant decreases of arboreal and riparian taxa, is then recorded at 3500 cal BP, reflecting a re-cultivation of the Guidel marsh (Fig. 5). During the Iron Age, the agricultural activity continues at a low level, while decreasing arboreal taxa, in parallel with increasing ruderal plants, suggest episodes of massive clearing for pastoral activities rather than for agricultural practices (Fig. 5). Regarding agricultural activities, archeological studies mention the presence of Iron Age villages in the upstream part of the Guidel site (González de la Aleja, 2008). The first significant increase of Cerealia pollen grains is observed during the Gallo-Roman period (Fig. 5), associated with a sharp decrease of the arboreal and riparian forests, this latter being relatively stable throughout the record until the Gallo-Roman period. This is also confirmed by archeological data, which attests to the Gallo-Roman occupation along the Sauldraye River (González de la Aleja, 2008). This population may have cleared the Guidel marsh in order to intensively develop cultivation. In the Bay of Brest (Pors Milin), the same observation has been made from a sharp decrease of the alluvial forest (mainly Alnus) at the start of the Gallo-Roman period (Fig. 5). The introduction of Juglans in the Armorican Domain, especially in the southern part of the region, indicates commercial practices, especially by the Venetii tribe. An early introduction, since the late Mesolithic period (8700 cal BP), of Juglans is suggested by several authors (Barbier and Visset, 1997; Visset et al., 2002), while it is commonly recognized that this taxon was introduced by Romans (Pitte, 1986) (Fig. 5). At the top of the record, covering the Middle Ages, the appearance of Fagopyrum signals a regional introduction of exotic plants imported from Asia. Also, the occurrence of Juglans, synchronous with a maximum development of Cerealia, suggests periods of intensification of agricultural activities, probably related to a major population expansion during the Middle Age Optimum.

\section{Conclusion}

Brittany is a perfect location in which to study past human settlement because of the numerous archeological sites and monuments found inland and along the coast. The present multiproxy study based on fossil bio-indicators (pollen) permits the reconstruction of environmental changes that took place on multi-decadal to centennial-time scales. At Guidel, both paleoenvironmental and archeological data allow us to discuss the role played by human and natural factors on vegetation changes. Comparison of vegetation shifts recorded at Guidel with mid-Neolithic archeological records suggests that human activity was important around the site and has impacted vegetation fluctuations between 6500 and $5500 \mathrm{cal} \mathrm{BP}$, but also that human displacement was provoked by climate shifts involving major storms. Our study suggests that during the Mid-Neolithic at Guidel the increase of storm events, combined with sea level change, has provoked coastal geomorphological changes (breaching of barrier dunes and redistribution of tidal channels also induced by increasing humidity), which caused abandonment of the coastal area by human societies. This study also points out substantial differences existing between the Neolithization process of northern and southern Brittany that may be explained by different geomorphological contexts: large coastal marshes in southern Brittany allowing human settlement and expansion, versus narrow coastal marshes in northern Brittany.

\section{Acknowledgments}

This study was supported by the French Research Program ANR COCORISCO, as well as the program PHILTRE funded by the Brittany Region. Much of the core dating was obtained thanks to the National ARTEMIS radiocarbon laboratory facilities. We would also like to thank the BRGM (Bureau de Recherches Minières et Méologiques) for their help in drilling the Grand Loc'h of Guidel. This work was supported by the "Laboratoire d'Excellence" LabexMER (ANR-10-LABX-19) and cofunded by a grant from the French Government under the program 
"Investissements d'Avenir", and by a grant from the Regional Council of Brittany.

\section{References}

Bailloud, G., Boujot, C., Cassen, S., Le Roux, C.-T., 1995. Carnac, les premières architectures de pierre. Collection Patrimoine au présent CNRS editions. (126 pp.).

Baltzer, A., Walter-Simonnet, A.-V., Mokeddem, Z., Tessier, B., Goubert, E., Cassen, S., Diffo, A., 2014. Climatically-driven impacts on sedimentation processes in the Bay of Quiberon (south Brittany, France). The Holocene 24, 679-688.

Barbier, D., Visset, L., 1997. Logn, a peat bog of European ecological interest in the Massif Armorican, western France: bog development, vegetation and land-use history. Veg. Hist. Archaeobotany 6, 69-77.

Barthelmes, A., Gerlof, D., Klerk, P., Joosten, H., 2010. Short-term vegetation dynamics of alnus dominated peatlands: a high resolution palaeoecological case study from Western Pomerania (NE Germany). Folia Geobotanica 45, 279-302.

Bennett, K.D., 1996. Determination of the number of zones in a biostratigraphical sequence. New Phytol. 132, 155-170.

Blaauw, M., 2010. Methods and code for "classical" age-modelling of radiocarbon sequences. Quat. Geochronol. 5, 512-518.

Blanchard, A., 2012. Le Néolithique récent de l'Ouest de la France (IVe - IIIe millénaires avant J-C.): productions et dynamiques culturelles PhD thesis, University of Rennes I (398 pp.).

Bond, G., Kromer, B., Beer, J., Muscheler, R., Evans, M.N., Showers, W., Hoffmann, S., LottiBond, R., Hajdas, I., Bonani, G., 2001. Persistent solar influence on North Atlantic climate during the Holocene. Science 294, 2130-2136.

Collins, E.S., Scott, D.B., Gayes, P.T., 1999. Hurricane records on the south Carolina coast: can they be detected in the sediment record? Ouat. Int. 56, 15-26.

D'Andrea, W.J., Huanga, Y., Fritz, S.C., Anderson, N.J., 2011. Abrupt Holocene climate change as an important factor for human migration in West Greenland. Proc. Natl. Acad. Sci. U. S. A. 108 (24), 9765-9769.

David, R., 2014. Modélisation de la végétation holocène du Nord-Ouest de la France: Reconstruction de la chronologie et de l'évolution du couvert végétal du Bassin parisien et du Massif armoricain PhD thesis, University of Rennes I (284 pp.).

Davis, B.A.S., Brewer, S., Stevenson, A.C., Guiot, J., Data Contributors, 2003. The temperature of Europe during the Holocene reconstructed from pollen data. Quat. Sci. Rev. $22,1701-1716$.

Fernane, A, 2014. Reconstitution des fluctuations holocènes en relation avec les changements climatiques et l'anthropisation sur les côtes bretonnes à partir de bioindicateurs fossiles (foraminifères benthiques, Chironomidae, pollen) PhD thesis, University of Brest (248 pp.).

Fernane, A., Gandouin, E., Penaud, A., Van Vliet-Lanoë, B., Goslin, J., Vidal, M., Delacourt, C. 2014. Coastal palaeoenvironmental record of the last 7 ka BP in NW France: submillenary climatic and anthropic Holocene signals. The Holocene 24, 1785-1797.

Fletcher, W.J., Debret, M., Sanchez Goñi, M.F., 2013. Mid-Holocene emergence of a lowfrequency millennial oscillation in western Mediterranean climate: implications for past dynamics of the North Atlantic atmospheric westerlies. The Holocene 23 153-166.

Gandouin, E. Ponel, P., Andrieu-Ponel, V., Guiter, F., de Beaulieu, J.L., Djamali, M., Franquet, E., Van Vliet-Lanoë, B., Alvitre, M., Meurisse, M., Brocandel, M., Brulhet, J., 2009. 10,000 years of vegetation history of the Aa palaeoestuary, St-Omer Basin, northern France. Rev. Palaeobot. Palynol. 156, 307-318.

Gaudin, L., 2004. Transformations spatio-temporelles de la végétation du nordouest de la France depuis la fin de la dernière glaciation. Reconstitutions paléo-paysagères $\mathrm{PhD}$ thesis, University of Rennes I (660 pp.).

Gebhardt, A., 1993. Micromorphological evidence of soil deterioration since the MidHolocene in Brittany, France. The Holocene 3, 333-341.

Gebhardt, A., Marguerie, D., 2006. Les sols, leur couvert végétal et leur utilisation au Néolithique. In: Le Roux, C.-T. (Ed.), Monuments mégalithiques à Locmariaquer (Morbihan). Gallia Préhistoire, CNRS Editions (13-23 pp.).

Giot, P.R., Briard, L., Pape, L., 1981. Protohistoire de la Bretagne. West France University (444 pp.).

González de la Aleja, E.L.-R., 2008. Monuments néolithiques de la région de Lorient (Morbihan, Bretagne): à propos des modes d'organisation des territoires. l'Anthropologie $112,572-597$.

Goslin, J., 2014. Holocene relative sea-level reconstruction in the Finistère region (Brittany, France): regional dynamics, local responses PhD Thesis, University of Brest (355 pp.).

Goslin, J., Van Vliet-Lanoë, B., Stéphan, P., Delacourt, C., Fernane, A., Gandouin, E., Hénaff A., Penaud, A., Suanez, S., 2013. Holocene relative sea-level changes in western Brittany (France) between 7600 and 4000 cal. BP: reconstitution from basal-peat deposits. Géomorphologie 4, 425-444

Gouézin, P., 1994. Les Mégalithes du Morbihan intérieur; des landes de Lanvaux au nord du département. Collection Patrimoine Archéologique de la Bretagne. Institut Culturel de Bretagne-Laboratoire d'Anthropologie-Préhistoire de l'université Rennes I (127 pp.).

Gouézin, P., 2007. Les Mégalithes du Morbihan littoral (au Sud des Landes de Lanvaux, de Guidel à Quiberon). Collection Patrimoine Archéologique de Bretagne, coédition I.C.B.-Ce.RAA (135 pp.)

Grudd, H., Briffa, K.R., Karlén, W., Bartholin, T.S., Jones, P.D., Kromer, B., 2002. A 7400-year tree-ring chronology in northern Swedish Lapland: natural climatic variability expressed on annual to millennial timescales. The Holocene 12, 657-665.

Hurrell, J.W., 1995. Decadal trends in the North Atlantic Oscillation: regional temperatures and precipitation. Science 269, 676-679.

Hyde, H.A., Adams, K.F., 1958. An Atlas of Airborne Pollen Grains. Macmillan \& Co., London.
Joly, C., Visset, L., 2009. Evolution of vegetation landscapes since the Late Mesolithic on the French West Atlantic coast. Rev. Palaeobot. Palynol. 154, 124-179.

Liu, K.B., Fearn, M.L., 1993. Lake-sediment record of late Holocene hurricane activities from coastal Alabama. Geology 21, 793-796.

Magny, M., 2004. Holocene climate variability as reflectedby mid-European lake-level fluctuations and its probable impact on prehistoric human settlements. Quat. Int. 113, 65-79.

Magny, M., Haas, J.N., 2004. A major widespread climatic change around 5300 cal. yr BP ago at the time of the Alpine Iceman. J. Quat. Sci. 19, 423-430.

Marchand, G., 2005. Les occupations mésolithiques à l'intérieur du Finistère. Bilan archéographique et méthodologique (2001-2003). Revue archéologique de l'ouest 22, pp. 25-84.

Marchand, G., 2014. Préhistoire Atlantique. Fonctionnement et évolution des sociétés du Paléolithique au Néolithique. Éditions Errance. (450 pp.)

Mayewski, P.A., Rohling, E.E., Curt Stager, J., Karlén, W., Maasch, K.A., David Meeker, L., Meyerson, E.A., Gasse, F., van Kreveld, S., Holmgren, K., Lee-Thorp, J., Rosqvist, G., Rack, F., Staubwasse, M., Schneider, R.R., Steig, E.J., 2004. Holocene climate variability. Quat. Res. 62, 243-255.

Meurisse-Fort, M., 2009. Enregistrement haute résolution des massifs dunaires: Manche, mer du Nord et Atlantique - Le rôle des tempêtes PhD Thesis, University of Lille 1 (312 pp.).

Moore, P., Webb, J., Collinson, M., 1991. Pollen Analysis. second edition.

Morzadec-Kerfourn, M., 1974. Variation de la ligne de rivage armoricaine au Quaternaire PhD Thesis, University of Rennes I (208 pp.).

Murray, J., 2006. Ecology and Applications of Benthic Foraminifera. Cambridge University Press, Cambridge (426 pp.).

Naughton, F., Bourillet, J.-F., Sanchez Goni, M.F., Turon, J.-L., Jouanneau, J.-M., 2007. Longterm and millennial-scale climate variability in northwestern France during the last 8850 years. The Holocene 17, 939-953.

Nicolas, C., Pailler, Y., Stéphan, P., Gandois, H., 2013. Les reliques de Lothéa (Quimperlé, Finistère): une tombe aux connexions atlantiques entre Campaniforme et Âge du Bronze ancien. Gallia Préhistoire 55 pp. 181-227.

Nilsson, S., Ppraglowski, J., Nilsson, L., 1977. Atlas of Airborne Pollen Grains and Spores in Northern Europe. Ljungforetagen, Orebro, Sweden.

O'Brien, S.R., Mayewski, P.A., Meeker, L.D., Meese, D.A., Twickler, M.S., Whitlow, S.I., 1995. Complexity of Holocene climate as reconstructed from a Greenland ice core. Science 270, 1962-1964.

Pailler, Y., Nicolas, C., 2014. Découverte d'objets néolithiques dans la Laïta (Finistère) entre Quimperlé et Le Pouldu en Clohars-Carnoët, in La forêt de Carnoët (Quimperlé). Archéologie, histoire, traditions et légendespp. 41-57.

Pitte, J.R., 1986. Terres de Castanide: Hommes et paysages du Châtaignier de l'Antiquité à nos jours. Fayard (480 pp.).

R Development Core Team, 2013. R: A language and environment for statistical computing. R Foundation for Statistical Computing, Vienna, Austria ISBN 3-900051-07-0, http://www.r-project.org.

Reille, M., 1995. Pollen et spores d'Europe et d'Afrique du nord. Laboratoire de botanique historique et palynologie, Marseille.

Reille, M., 1999. Pollen et spores d'Europe et d'Afrique du Nord. Laboratoire de botanique historique et palynologie, p. 584

Reimer, P.L., Bard, E., Bayliss, A., Beck, J.W., Blackwell, P.G., Ramsey, C.B., Buck, K.E., Cheng, H., Edwards, R.L., Friedrich, M., Grootes, P.M., Guilderson, T.P., Haflidason, H., Hajdas, I., Hatté, C., Heaton, T.J., Hoffmann, D.L., Hogg, A.G., Hughen, C.A., Kaiser, K.F., Kromer, B., Manning, S.W., Niu, M., Reimer, R.W., Richards, D.A., Scott, E.M., Southon, J.R., Staff, R.A., Turney, C.S.M., van der Plicht, J., 2013. IntCal13 and Marine13 radiocarbon age calibration curves 0-50,000 cal years BP. Radiocarbon 55, 1869-1887.

Rossi, V., Horton, B.P., Corbett, D.R., Leorri, E., Perez-Belmonte, L., Douglas, B.C., 2011. The application of foraminifera to reconstruct the rate of 20th century sea level rise, Morbihan Golfe, Brittany, France. Quat. Res. 75, 24-35.

Sabatier, P., Dezileau, L., Colin, C., Briqueu, L., Bouchette, F., Martinez, P., Siani, G., Raynal, O., Grafenstein, U.V., 2012. 7000 years of palaeostorm activity in the NW Mediterranean Sea in response to Holocene climate events. Quat. Res. 77, 1-11.

Scott, D.B., Medioli, F.S., Schafer, C.T., 2001. Monitoring in Coastal Environment Using Foraminifera and the Camoebian Indicators. Cambridge University Press, Cambridge (177 pp.).

Sorrel, P., Tessier, B., Demory, F., Delsinne, N., Mouazé, D., 2009. Evidence for millennialscale climatic events in the sedimentary infilling of a macrotidal estuarine system, the Seine estuary (NW France). Quat. Sci. Rev. 28, 499-516.

Sorrel, P., Debret, M., Billeaud, I., Jaccard, S.L., MacManus, J.F., Tessier, B., 2012. Persistent non-solar forcing of Holocene storm dynamics in coastal sedimentary archives. Nat. Geosci. 5, 892-896.

Stéphan, P., Goslin, J., Pailler, Y., Manceau, R., Suanez, S., Van Vliet-Lanoë, B., Hénaff, A., Delacourt, C, 2015. Holocene salt-marsh sedimentary infilling and relative sea-level changes in West Brittany (France) using foraminifera-based transfer functions. Boreas 44, 153-177.

Stewart, A.V., 1996. Plantain (Plantago lanceolata) - a potential pasture species. Proceedings of the New Zealand Grassland Association 58 pp. 77-86.

Stolze, S., Muscheler, R., Dörfler, W., Nelle, O., 2013. Solar influence on climate variability and human development during the Neolithic: evidence from a high-resolution multi-proxy record from Templevanny Lough, County Sligo, Ireland. Quat. Sci. Rev. 67, 138-159.

Tanguy, B., Lagree, M., 2002. Atlas d'Histoire de Bretagne. Editions Skol Vreizh. University of Brittany (CRBC) et le CHRISCO (University of Rennes I) (172 pp.).

Van Vliet-Lanoë, B., Penaud, A., Hénaff, A., Delacourt, C., Fernane, A., Goslin, J., Hallegouët, B., Le Cornec, E., 2014. Middle- to late-Holocene storminess in Brittany (NW France): part II-the chronology of events and climate forcing. The Holocene 24, 434-453.

Visset, L., 1994. Vegetation changes and development of agriculture at "Kerfontaine" (Sérent, Massif Armoricain, France). Veg. Hist. Archaeobotany 3, 1-6. 
Visset, L., L'Helgouach, J., Bernard, J., 1996. La tourbière submergée de la pointe de Kerpenhir à Locmariaquer (Morbihan). Etude environnementale et mise en évidence de déforestations et de pratiques agricoles néolithiquesRevue archéologique de l'ouest 13 pp. 79-87.

Visset, L., Cyprien, A.-L., Carcaud, N., Ouguerram, A., Barbier, D., Bernard, J., 2002. Les prémices d'une agriculture diversifiée à la fin du Mésolithique dans le Val de Loire (Loire armoricaine, France). C. R. Palevol 1, 51-58.
Wanner, H., Beer, J., Bütikofer, J., Crowley, T.J., Cubasch, U., Flückiger, J., Goosse, H., Grosjean, M., Joos, F., Kaplan, J.O., Kü ttel, M., Müller, S.M., Prentice, I.C., Solomina, O., Stocker, T.F., Tarasov, P., Wagner, M., Widmann, 2008. Mid- to Late Holocene climate change: an overview. Quat. Sci. Rev. 27, 1791-1828.

Wanner, H., Solomina, O., Grosjean, M., Ritz, S.P., Jetel, M., 2011. Structure and origin of Holocene cold events. Quat. Sci. Rev. 30, 3109-3123. 